\title{
Safety evaluation of allogeneic umbilical cord blood mononuclear cell therapy for degenerative conditions
}

\author{
Wan-Zhang Yang ${ }^{1}$, Yun Zhang ${ }^{2}$, Fang Wu', Wei-Ping Min³ ${ }^{3}$ Boris Minev ${ }^{4}$, Min Zhang ${ }^{1}$, Xiao-Ling Luo², \\ Famela Ramos ${ }^{5}$, Thomas E Ichim ${ }^{5}$, Neil H Riordan ${ }^{5+}$, Xiang $\mathrm{Hu}^{2^{*+}}$
}

\begin{abstract}
Background: The current paradigm for cord blood transplantation is that HLA matching and immune suppression are strictly required to prevent graft versus host disease (GVHD). Immunological arguments and historical examples have been made that the use of cord blood for non-hematopoietic activities such as growth factor production, stimulation of angiogenesis, and immune modulation may not require matching or immune suppression.

Methods: 114 patients suffering from non-hematopoietic degenerative conditions were treated with non-matched, allogeneic cord blood. Doses of 1-3 $\times 10^{7}$ cord blood mononuclear cells per treatment, with 4-5 treatments both intrathecal and intravenously were performed. Adverse events and hematological, immunological, and biochemical parameters were analyzed for safety evaluation.

Results: No serious adverse effects were reported. Hematological, immunological, and biochemical parameters did not deviate from normal ranges as a result of therapy.

Conclusion: The current hematology-based paradigm of need for matching and immune suppression needs to be revisited when cord blood is used for non-hematopoietic regenerative purposes in immune competent recipients.
\end{abstract}

\section{Background}

Cord blood mononuclear cells are comprised of a heterogenous population of hematopoietic and mesenchymal stem cells, endothelial progenitor cells, and immature immunological cells $[1,2]$. The conventional medical use of cord blood is limited to hematopoietic reconstitution [3], with clinical trials ongoing in type I diabetes [4], and cerebral palsy [5]. Preclinical studies have demonstrated efficacy of cord blood in diverse conditions ranging from heat stroke [6,7], to amyotrophic lateral sclerosis [8], to post infarct regeneration [9], to liver failure [10].

In hematopoietic stem cell transplants ablation of recipient marrow is required to eradicate the endogenous stem cell compartment, and HLA matching with post transplant immune suppression is used to prevent GVHD [3]. For non-hematopoietic applications such as

\footnotetext{
* Correspondence: huxiang@beike.cc

† Contributed equally

${ }^{2}$ Shenzhen Beike Cell Engineering Research Institute, Shenzhen, China

Full list of author information is available at the end of the article
}

cardiovascular or neurological indications, the therapeutic activities of the cord blood are believed to be mediated in many cases by growth factor secretion $[11,12]$, therefore permanent graft survival is not essential. In these situations the use of non-matched, allogeneic cells may be acceptable. The major barrier to this approach is the theoretical fear of inducing GVHD.

From practical experience there is some evidence that in immune competent recipients, non-matched allogeneic cord blood cells do not elicit GVHD. Specifically: a) Recipients of cord blood in the transfusion scenario, in some cases up to 37 units, have not reported GVHD; b) $\mathrm{T}$ cells comprise the GVHD-causing component of cord blood. Administration of allogeneic lymphocytes for prevention of recurrent spontaneous abortion has not led to GVHD, despite higher $\mathrm{T}$ cell doses than found in cord blood transplants; and c) Despite presence of fetal T cells in mothers, GVHD associated with pregnancy has not been reported [13].

\section{Biomed Central}

(c) 2010 Yang et al; licensee BioMed Central Ltd. This is an Open Access article distributed under the terms of the Creative Commons Attribution License (http://creativecommons.org/licenses/by/2.0), which permits unrestricted use, distribution, and reproduction in any medium, provided the original work is properly cited. 
Under the practice of medicine, several treatment facilities have been using cord blood stem cells without matching or immune suppression [14-17]. Despite identification of a "clinical signal", studies have been extremely limited in patient numbers. In the current report we analyzed safety parameters of 114 patients treated with non-matched, allogeneic cord blood mononuclear cells. Treatments included intravenous and intrathecal administration. No immunological reactions, GVHD, or serious adverse effects were observed. Hematological, biochemical, and immunological parameters remained within normal range.

\section{Methods}

\section{Patient characteristics}

Data reported was collected from patients treated during August 2005-July 2007 as part of medical practice at the Nanshan Affiliated Hospital of Guangdong Medical College. All patients were free of: 1) prior history of severe allergic reactions; 2) history of, or active, malignancy; 3 ) active systemic or severe focal infections (including HIV and syphilis); 4) active cardiac, pulmonary, renal, hepatic or gastrointestinal disease; 5) coagulopathy or any other contraindication for lumbar puncture; 6) gastrostomy, tracheostomy or noninvasive ventilatory support - as these could influence the prognosis and end-point measurements; 7) any severe psychiatric disorder and 8) any immunodeficiency disease or condition.

Age range was 15 to 68 and the male:female ratio was 1.6:1 (70 males, 44 females). In terms of diagnosis, 4 patients had multiple system atrophy (MSA), 23 patients had ataxias, 42 patients were paraplegic, 19 patients had multiple sclerosis, 12 patients had Amyotrophic Lateral Sclerosis (ALS) and 14 patients had other diagnoses (Table 1). The local institutional review board of the Nanshan Affiliated Hospital of Guangdong Medical College, under the auspices of the National Ministry of

Table 1 Patients treated by condition

\begin{tabular}{lc}
\hline Condition & Number of patients \\
\hline Paraplegia & 42 \\
Ataxia & 23 \\
Multiple Sclerosis & 19 \\
Amyotrophic Lateral Sclerosis & 12 \\
Sequelae of Cerebrovascular Diseases & 6 \\
Multiple System Atrophy & 4 \\
Motor Neuron Disease & 2 \\
Cerebral Palsy & 1 \\
Nerve Injury (Brachial plexus) & 1 \\
Traumatic Brain Injury Sequelae & 1 \\
Hypoxic-ischemic Encephalopathy Sequelae & 1 \\
Cervical Spondylotic Myelopathy & 1 \\
Optic Nerve Hypoplasia & 1 \\
\hline
\end{tabular}

Heath, approved application of the technique and consent forms were obtained from each patient before initiation of treatment.

\section{Cell processing}

Umbilical Cord Blood (100 $150 \mathrm{~mL}$ ) was collected from healthy unrelated donors (signed an informed consent) in accordance with the sterile procurement guidelines for cord blood in each hospital. After collection, each blood sample was tested for communicable diseases such as HBV, HCV, HIV, ALT, and Syphilis. Cord blood was diluted with saline in the ratio $2: 1$ and $30 \mathrm{mls}$ of the diluted blood was then added to $15 \mathrm{mls}$ of Ficoll in every $50 \mathrm{ml}$ centrifuge tube and then centrifuged (750 g $\times 22$ minutes). Mononuclear cells were collected and washed twice in saline. Contaminating erythrocytes were lyzed with lysis buffer comprising of injection grade water.

Cell density was adjusted to $2 \sim 6 \times 10^{6} / \mathrm{ml}$ and seeded in DMEM/F12 culture medium with bFGF and EGF at a concentration of $20 \mathrm{ng} / \mathrm{ml}$. Culture media was mixed with 2\% v/v B-27 Stem Cell Culture Supplements. Cells were cultured at $37^{\circ} \mathrm{C}$ with saturated humidity and $5 \% \mathrm{CO} 2$ by volume. At this stage, all relevant information about the initial culture is entered in the batch information record including test results for sterility, mycoplasma and endotoxin. Cell growth was regularly monitored and the inspection records updated accordingly. Cells were harvested for clinical application after one week of cultivation with cell quantity $\geq 1 \times 10^{7}$ and viability $\geq 95 \%$.

To ensure the quality of the UCB-derived mononuclear cells, a number of parameters are confirmed before use. These are as follows: 1) Raw material control: Tests (HBV, HCV, HIV, ALT and Syphilis) for communicable diseases for UCB units are carried out before any processing begins. Testing was performed by third party laboratory under local government-monitored conditions.

2) In-process control: Non-qualifying cells were eliminated in accordance with Beike's cell counting and morphology standards which include cell quantity $\geq 1 \times 10^{7}$ and the highly homogeneous cells possessing a round shape and non-adherence to the culture flask.

3) Culture control: Any contaminated cell suspensions or unhealthy cells were eliminated upon discovery. Non-contamination was determined as lack of sterility, mycoplasma, and lack of visible microorganisms by microscopy. Furthermore samples had to have an endotoxin level $\leq 0.5 \mathrm{EU} / \mathrm{ml}$ and be negative for free DNA.

4) Finished product control: This incorporates a final cell count $\left(\geq 1 \times 10^{7}\right.$, containing 1.0-2.0\% CD34+ cells as determined by flow cytometry), cell viability ( $\geq 95 \%)$ and sterility test. 


\section{Cell administration}

Intrathecal injection by lumbar puncture was combined with intravenous infusion and repeated four or five times - depending on the patient's condition. Treatments were separated by one week intervals. Lumbar puncture was performed in the lateral decubitus position, prepped and draped in sterile fashion, and the needle placed in the lumbar cistern. Two mls of Cerebro-Spinal Fluid (CSF) was removed and replaced by 2 mls of cell suspension containing $1-3 \times 10^{7}$ cells. A $30 \mathrm{ml}$ intravenous infusion of cell suspension was given through an intravenous catheter in 15-20 minutes.

\section{Statistics}

Adverse events were analyzed for all 114 cases, and are presented as percentage values. For analysis of laboratory parameters, the continuous variables were compared using Student t-test with alpha set at 0.05 by group. When the data set did not conform to the normal distribution, logarithmic transformation was used. Inter-quartile-range (IQR) computation and boxplots were used to detect outliers. The outliers were firmly believed to be data errors or data entry errors and were removed from the data analysis. The SPSS 13.0 statistical package was applied for statistical analysis.

\section{Results}

Administration of cord blood mononuclear cells via intrathecal and intravenous routes was well tolerated. No allergic or immunological reactions were noted at the time of injection or while under observation. Analysis of overall adverse events (Table 2) for a 4-5 week follow-up time period indicated headache as the most common (3.21\%). In all cases headaches were transient in nature. No deviation outside of reference ranges was observed for hematological (Table 3), biochemical (Table 4), or immunological (Table 5) measurements. Average follow-up time for post-treatment analysis was 30 days. Some pre and post treatment differences reaching statistical significance were however observed.

Slight but statistically significant alterations in mean hematological values were noted. Treatment was associated with increased total leukocyte $6.94 \pm 1.57$ vs $7.85 \pm 2.25$, neutrophil $59.70 \pm 10.39$ vs $65.03 \pm 13.06$, and platelet $193.94 \pm 47.64$ vs $206.21 \pm 54.52$ counts. Reduction in lymphocyte $30.23 \pm 9.20$ vs $26.03 \pm 10.32$, $\mathrm{RBC} 4.61 \pm 0.51$ vs $4.47 \pm 0.46$, and $\mathrm{MCH} 137.02 \pm$ 14.54 vs $132.88 \pm 13.98$ was observed (Table 3 ).

Total bilirubin $1.13 \pm 0.14$ vs $1.09 \pm 0.15$, total protein $65.03 \pm 5.27$ vs $63.20 \pm 6.27$, GPT $1.37 \pm 0.22$ vs $1.33 \pm$ 0.20 , GOT $23.60 \pm 12.45$ vs $21.01 \pm 8.56$, and creatinine $1.81 \pm 0.16$ vs $1.81 \pm 0.16$ where significantly decreased after treatment, whereas BUN and uric acid were not altered (Table 4).

CD3 T cells $79.91 \pm 6.78$ vs $77.67 \pm 8.18$, CD4 T cells $48.84 \pm 9.03$ vs $45.44 \pm 10.65$, and the $\mathrm{CD} 4 / \mathrm{CD} 8$ ratio $0.30 \pm 0.20$ vs $0.24 \pm 0.23$ were decreased, whereas an increase in CD8 cells was observed with treatment 25.38 \pm 7.18 vs $26.89 \pm 8.10$. Of soluble immune parameters, $\mathrm{C} 3$ and C4 were not affected by treatment, whereas IgG $0.96 \pm 0.12$ vs $0.91 \pm 0.14$ and $\operatorname{IgA} 2.15 \pm 0.79$ vs $2.01 \pm$ 0.72 levels were decreased. An increase in IgM levels $1.13 \pm 0.62$ vs $1.32 \pm 0.72$ was noted post treatment (Table 5).

\section{Discussion}

The possibility of using non-matched, allogeneic cord blood cells for regenerative medicine applications in absence of immune suppression would overcome several substantial hurdles existing today in stem cell therapy. Although cord blood derived cells are superior to bone marrow in terms of growth factor production ability, pluripotency, and immune modulating activity $[18,19]$, their use has been limited to autologous sources for regenerative applications. The reason for this is has been the argument that the potential adverse effects of myeloablative therapy outweigh possible regenerative activities. The current study investigated the safety of allogeneic cord blood cells for use in regenerative applications in absence of immune suppression.

No serious adverse effects were observed. The most common adverse reaction reported was headache (3.21\%), some of which was believed to be caused by postural hypotensive headaches, which is a known

Table 2 Analysis of adverse events (AE)

\begin{tabular}{cccc}
\hline AE & Total injections in person time & Number of AE by type (person-time) & Incidence of AE \\
\hline Headache & 592 & 19 & $3.21 \%$ \\
\hline Fever & 592 & 7 & $1.18 \%$ \\
\hline Waist pain & 592 & 5 & $0.84 \%$ \\
\hline Shivering & 592 & 3 & $0.51 \%$ \\
\hline Vomiting & 592 & 2 & $0.34 \%$ \\
\hline Lower limb pain & 592 & 2 & $0.34 \%$ \\
\hline Total & 592 & 38 & 6.42 \\
\hline
\end{tabular}


Table 3 Hematology

\begin{tabular}{ccccccc}
\hline Parameter & $\begin{array}{c}\text { Number of } \\
\text { patients }\end{array}$ & $\begin{array}{c}\text { Before } \\
\text { treatment }\end{array}$ & $\begin{array}{c}\text { After } \\
\text { treatment }\end{array}$ & $\begin{array}{c}\text { Reference } \\
\text { range }\end{array}$ & $\begin{array}{c}\mathbf{P} \\
\text { value }\end{array}$ & Significance \\
\hline Leukocytes $\left(\times 10^{9} / \mathrm{L}\right)$ & 114 & $6.94(1.57)$ & $7.85(2.25)$ & $4.0-10.0$ & $<0.001$ & In normal range but significantly elevated \\
after treatment
\end{tabular}

Table 4 Serum chemistry

\begin{tabular}{|c|c|c|c|c|c|c|}
\hline Parameter & $\begin{array}{l}\text { Number of } \\
\text { patients }\end{array}$ & $\begin{array}{l}\text { Before } \\
\text { treatment }\end{array}$ & $\begin{array}{c}\text { After } \\
\text { treatment }\end{array}$ & $\begin{array}{l}\text { Reference } \\
\text { range }\end{array}$ & $\begin{array}{c}P \\
\text { value }\end{array}$ & Significance \\
\hline Total bilirubin $(\mu \mathrm{mol} / \mathrm{L})$ & 113 & $1.13(0.14)$ & $1.09(0.15)$ & $0.23-1.35$ & 0.002 & $\begin{array}{l}\text { In normal range but significantly decreased } \\
\text { after treatment }\end{array}$ \\
\hline Total protein (g/L) & 114 & $65.03(5.27)$ & $63.20(6.27)$ & $60.0-85.0$ & 0.002 & $\begin{array}{c}\text { In normal range but significantly decreased } \\
\text { after treatment }\end{array}$ \\
\hline $\begin{array}{c}\text { Glutamic-pyruvic transaminase, } \\
\text { (GPT) (U/L) }\end{array}$ & 114 & $1.37(0.22)$ & $1.33(0.20)$ & $0.7-1.65$ & 0.037 & $\begin{array}{c}\text { In normal range but significantly decreased } \\
\text { after treatment }\end{array}$ \\
\hline $\begin{array}{c}\text { Glutamic-oxaloacetic transaminase } \\
(\mathrm{GOT})(\mathrm{U} / \mathrm{L})\end{array}$ & 114 & $23.60(12.45)$ & $21.01(8.56)$ & $5.0-45.0$ & 0.005 & $\begin{array}{l}\text { In normal range but significantly decreased } \\
\text { after treatment }\end{array}$ \\
\hline $\begin{array}{l}\text { Serum urea nitrogen }(B \cup N) \\
(\mu \mathrm{mol} / \mathrm{L})\end{array}$ & 114 & $4.63(1.58)$ & $4.58(1.88)$ & $2.0-7.1$ & 0.750 & In normal range, no significant difference \\
\hline Serum creatinine $(S C R)(\mu \mathrm{mol} / \mathrm{L})$ & 114 & $1.81(0.16)$ & $1.81(0.16)$ & $1.64-2.12$ & 0.898 & In normal range, no significant difference \\
\hline Uric acid $(U A)(\mu \mathrm{mol} / \mathrm{L})$ & 114 & $308.27(80.88)$ & $\begin{array}{l}309.28 \\
(89.64)\end{array}$ & $90.0-440.0$ & 0.871 & In normal range, no significant difference \\
\hline
\end{tabular}

Table 5 Immunological parameters

\begin{tabular}{|c|c|c|c|c|c|c|}
\hline Parameter & $\begin{array}{l}\text { Number of } \\
\text { patients }\end{array}$ & $\begin{array}{l}\text { Before } \\
\text { treatment }\end{array}$ & $\begin{array}{c}\text { After } \\
\text { treatment }\end{array}$ & $\begin{array}{l}\text { Reference } \\
\text { range }\end{array}$ & $\begin{array}{c}P \\
\text { value }\end{array}$ & Significance \\
\hline T-cells (CD3)\% of total T cells & 113 & $79.91(6.78)$ & $77.67(8.18)$ & $61-85$ & 0.001 & $\begin{array}{c}\text { In normal range but significantly decreased } \\
\text { after treatment }\end{array}$ \\
\hline $\begin{array}{c}\text { Helper T-cell (Th cell/CD4) \% of } \\
\text { total T cells } \\
\end{array}$ & 114 & $48.84(9.03)$ & $45.44(10.65)$ & $28-58$ & $<0.001$ & $\begin{array}{c}\text { In normal range but significantly decreased } \\
\text { after treatment }\end{array}$ \\
\hline Ts cell (CD8)\% of total T cells & 114 & $25.38(7.18)$ & $26.89(8.10)$ & $19-48$ & 0.005 & $\begin{array}{c}\text { In normal range but significantly increased } \\
\text { after treatment }\end{array}$ \\
\hline $\mathrm{CD} 4 / \mathrm{CD} 8$ & 114 & $0.30(0.20)$ & $0.24(0.23)$ & $-0.05-0.30$ & $<0.001$ & $\begin{array}{l}\text { In normal range but significantly decreased } \\
\text { after treatment }\end{array}$ \\
\hline $\lg G(g / L)$ & 114 & $0.96(0.12)$ & $0.91(0.14)$ & $0.86-1.23$ & $<0.001$ & $\begin{array}{c}\text { In normal range but significantly decreased } \\
\text { after treatment }\end{array}$ \\
\hline $\lg A(g / L)$ & 114 & $2.15(0.79)$ & $2.01(0.72)$ & $0.68-3.83$ & $<0.001$ & $\begin{array}{c}\text { In normal range but significantly decreased } \\
\text { after treatment }\end{array}$ \\
\hline $\lg M(g / L)$ & 114 & $1.13(0.62)$ & $1.32(0.72)$ & $0.63-2.77$ & $<0.001$ & $\begin{array}{c}\text { In normal range but significantly increased } \\
\text { after treatment }\end{array}$ \\
\hline Complement C3 (g/L) & 114 & $1.19(0.23)$ & $1.21(0.25)$ & $0.85-1.93$ & 0.103 & $\begin{array}{c}\text { In normal range but no significant changes } \\
\text { after treatment }\end{array}$ \\
\hline Complement C4 (g/L) & 114 & $-0.62(0.17)$ & $-0.63(-0.16)$ & $-0.92--0.44$ & 0.283 & $\begin{array}{c}\text { In normal range but no significant changes } \\
\text { after treatment }\end{array}$ \\
\hline
\end{tabular}


complication of lumbar puncture procedures. These symptoms chronologically followed the treatment, and resolved spontaneously without aggressive intervention. These findings are consistent with a Boston Children's Hospital's study that recorded a similar adverse reaction profile to cryopreserved (CD34+) hematopoietic stem cells in the treatment of children [20]. These incidence rates are also similar to those of the published PBPC and Ficoll groups (grouped by isolation method).

Of the full range of laboratory parameters in the analysis, only the changes of lymphocyte (decreased) and neutrophil (increased) count could be described as medically significant. A key contributing factor to these changes is possibly the fact that most patients received an intravenous injection of dexamethasone ( $5 \mathrm{mg}$, once) prior to each stem cell injection, to suppress possible adverse reactions. It has been reported that dexamethasone affects white blood cells, segmented neutrophils and lymphocytes [21], and that dexamethasone at therapeutic doses can have a suppressive effect on the lymphocyte proliferative response.

\section{Conclusion}

In summary, these data support the safety and freedom from immunologically-mediated adverse effects of allogeneic cord blood therapy in absence of immune suppression/myeloablation. This study presents for the first time a detailed safety analysis of using non-matched, allogeneic cord blood cells to treat non-hematopoietic degenerative conditions. The longest follow-up with this protocol was 4 years with no evidence of immune reactivity or GVHD. Evaluation of therapeutic benefit is currently in progress.

\section{Author details \\ ${ }^{1}$ Nanshan Affiliated Hospital of Guangdong Medical College, Shenzhen, China. ${ }^{2}$ Shenzhen Beike Cell Engineering Research Institute, Shenzhen, China. ${ }^{3}$ Department of Surgery, University of Western Ontario, London, Ontario, Canada. ${ }^{4}$ Department of Medicine, Division of Neurosurgery, University of California San Diego, San Diego, CA, USA. ${ }^{5}$ Medistem Inc, San Diego, CA, USA. \\ Authors' contributions \\ WY conceived of the study, participated in its design and coordination and carried out the clinical treatment. $Y Z$ analyzed and interpreted data and drafted the manuscript. FW carried out the clinical treatment and collected data. WM analyzed data and helped to draft the manuscript. BM participated in the data analysis and helped to draft the manuscript. MZ participated in the design of the study and carried out the clinical treatment. XL carried out the clinical treatment and performed the statistical analysis. TI helped to draft the manuscript. FR, TEI and NR analyzed and interpreted data, performed the statistical analysis and helped to draft the manuscript. $\mathrm{XH}$ conceived of the study, participated in its design and coordination and helped to draft the manuscript. All authors read and approved the final manuscript.}

\section{Competing interests}

Xiang $\mathrm{Hu}$ is a shareholder of Beike Biotechnology. No other authors declare any competing interests.
Received: 2 April 2010 Accepted: 3 August 2010

Published: 3 August 2010

\section{References}

1. Javed MJ, Mead LE, Prater D, Bessler WK, Foster D, Case J, Goebel WS, Yoder MC, Haneline LS, Ingram DA: Endothelial colony forming cells and mesenchymal stem cells are enriched at different gestational ages in human umbilical cord blood. Pediatr Res 2008, 64:68-73.

2. Hutton JF, Gargett T, Sadlon TJ, Bresatz S, Brown CY, Zola H, Shannon MF, D'Andrea RJ, Barry SC: Development of CD4+CD25+FoxP3+ regulatory T cells from cord blood hematopoietic progenitor cells. J Leukoc Biol 2009, 85:445-451.

3. Gratwohl A, Baldomero $\mathrm{H}$ : Trends of hematopoietic stem cell transplantation in the third millennium. Curr Opin Hematol 2009, 16:420-426.

4. Haller MJ, Wasserfall CH, McGrail KM, Cintron M, Brusko TM, Wingard JR, Kelly SS, Shuster JJ, Atkinson MA, Schatz DA: Autologous umbilical cord blood transfusion in very young children with type 1 diabetes. Diabetes Care 2009, 32:2041-2046.

5. Harris DT: Non-haematological uses of cord blood stem cells. $\mathrm{Br} \mathrm{J}$ Haematol 2009, 147:177-184.

6. Liu WS, Chen CT, Foo NH, Huang HR, Wang JJ, Chen SH, Chen TJ: Human umbilical cord blood cells protect against hypothalamic apoptosis and systemic inflammation response during heatstroke in rats. Pediatr Neonatol 2009, 50:208-216.

7. Hwang WS, Chen SH, Lin CH, Chang HK, Chen WC, Lin MT: Human umbilical cord blood-derived CD34+ cells can be used as a prophylactic agent for experimental heatstroke. J Pharmacol Sci 2008, 106:46-55.

8. Garbuzova-Davis S, Willing AE, Zigova T, Saporta S, Justen EB, Lane JC, Hudson JE, Chen N, Davis CD, Sanberg PR: Intravenous administration of human umbilical cord blood cells in a mouse model of amyotrophic lateral sclerosis: distribution, migration, and differentiation. $J$ Hematother Stem Cell Res 2003, 12:255-270.

9. Xing YL, Shen LH, Li HW, Zhang YC, Zhao L, Zhao SM, Xu Q: Optimal time for human umbilical cord blood cell transplantation in rats with myocardial infarction. Chin Med J (Engl) 2009, 122:2833-2839.

10. Moon YJ, Yoon HH, Lee MW, Jang IK, Lee DH, Lee JH, Lee SK, Lee KH, Kim YJ, Eom YW: Multipotent progenitor cells derived from human umbilical cord blood can differentiate into hepatocyte-like cells in a liver injury rat model. Transplant Proc 2009, 41:4357-4360.

11. Bachstetter AD, Pabon MM, Cole MJ, Hudson CE, Sanberg PR, Willing AE, Bickford PC, Gemma C: Peripheral injection of human umbilical cord blood stimulates neurogenesis in the aged rat brain. BMC Neurosci 2008 9:22.

12. Xiao J, Nan Z, Motooka Y, Low WC: Transplantation of a novel cell line population of umbilical cord blood stem cells ameliorates neurological deficits associated with ischemic brain injury. Stem Cells Dev 2005, 14:722-733.

13. Riordan $\mathrm{NH}$, Chan $\mathrm{K}$, Marleau AM, Ichim TE: Cord blood in regenerative medicine: do we need immune suppression? J Transl Med 2007, 5:8.

14. Ghen MJ, Roshan R, Roshan RO, Blyweiss DJ, Corso N, Khalili B, Zenga WT: Potential clinical applications using stem cells derived from human umbilical cord blood. Reprod Biomed Online 2006, 13:562-572.

15. Ichim TE, Solano F, Brenes R, Glenn E, Chang J, Chan K, Riordan NH: Placental mesenchymal and cord blood stem cell therapy for dilated cardiomyopathy. Reprod Biomed Online 2008, 16:898-905.

16. Riordan NH, Ichim TE, Min WP, Wang H, Solano F, Lara F, Alfaro M, Rodriguez JP, Harman RJ, Patel AN, Murphy MP, Lee RR, Minev B: Nonexpanded adipose stromal vascular fraction cell therapy for multiple sclerosis. J Transl Med 2009, 7:29.

17. Ichim TE, Alexandrescu DT, Solano F, Lara F, Campion Rde N, Paris E, Woods EJ, Murphy MP, Dasanu CA, Patel AN, Marleau AM, Leal A, Riordan $\mathrm{NH}$ : Mesenchymal stem cells as anti-inflammatories: implications for treatment of Duchenne muscular dystrophy. Cell Immunol 260:75-82.

18. Yoo KH, Jang IK, Lee MW, Kim HE, Yang MS, Eom Y, Lee JE, Kim YJ, Yang SK, Jung HL, Sung KW, Kim CW, Koo HH: Comparison of immunomodulatory properties of mesenchymal stem cells derived from adult human tissues. Cell Immunol 2009, 259:150-156.

19. Hwang JH, Shim SS, Seok OS, Lee HY, Woo SK, Kim BH, Song HR, Lee JK, Park YK: Comparison of cytokine expression in mesenchymal stem cells 
from human placenta, cord blood, and bone marrow. J Korean Med Sci 2009, 24:547-554.

20. Jiang ChF WCX, Fu YSh: Adverse reactions to blood transfusion and transfusion transmitted disease. GuangDong, CHINA, Guangdong Science and Technology press, 1 2004, 222.

21. Peng CT, Lin HC, Lin YJ, Tsai CH, Yeh TF: Early Dexamethasone Therapy and Blood Cell Count in Preterm Infants. Pediatrics 1999, 104:476-481.

doi:10.1186/1479-5876-8-75

Cite this article as: Yang et al: Safety evaluation of allogeneic umbilical cord blood mononuclear cell therapy for degenerative conditions. Journal of Translational Medicine 2010 8:75.

Submit your next manuscript to BioMed Central and take full advantage of:

- Convenient online submission

- Thorough peer review

- No space constraints or color figure charges

- Immediate publication on acceptance

- Inclusion in PubMed, CAS, Scopus and Google Scholar

- Research which is freely available for redistribution

Submit your manuscript at www.biomedcentral.com/submit
C Biomed Central 